\title{
Sürdürülebilir Otel Paradigmasının, Turizm İşletmelerinde Uygulanabilirliği Üzerine Bir Araştırma
}

\author{
Nil KONYALILAR*
}

Öz

$\mathrm{Bu}$ yazının amacı, turizm işletmelerinde sürdürülebilir otel paradigmasının uygulanabilirliğini araştırmaktır. Çevre bilincinin hızla arttığı ve rekabetin gittikçe daha da zorlaştığı turizm pazarında sürdürülebilirliğin sürdürülebilirliği, turizm bilinci artırıcı işletmeler açısından önemli faydalar sağlayabilir. Çalışmanın evrenini Kocaeli Kartepe'de faaliyet gösteren 9 otelde çalışan 530 kişi oluşturuyor. Bu nedenle, örnek hesaplama tablosuna göre 345 kişi olarak belirlenmiştir. Çalışmaya katılanlardan elde edilen veriler için Sürdürülebilir Otel Paradigması Ölçeği ve Sürdürülebilirlik Uygulanabilirlik Ölçeği kullanılmıștır. Yapılan analizler sonucunda, çalışanların yaş değişkenlerinin, sürdürülebilirlik sağlanması açısından hizmet içi ve okul dişı eğitimlerin çevre üzerindeki artışına istatistiksel olarak etkisi olduğu belirlenmiştir. Ayrıca, eğitimdeki artış ve çevre kirliliğinin yokluğu arasında da pozitif bir ilişki bulunmuştur. Tüketicilerin ihtiyaçlarının karşılanması ve çevre kirliliğinin önlenmesi için çevre koruma alanında teşvik edilmesi arasında bir ilişki olduğu tespit edilmiştir.

Anahtar Kelimeler: Sürdürülebilirlik, Sürdürülebilir Otel, Ekolojik Denge, Çevre Duyarlılığı, Turizm İşletmeleri

\section{An Investigation on the Applicability of the Sustainable Hotel Paradigm in Tourism Businesses}

\begin{abstract}
The purpose of this article is to investigate the applicability of the sustainable hotel paradigm in tourism businesses. The successful continuity of sustainability and awareness raising of employees in the tourism market where environmental awareness is increasing rapidly and competition is becoming more and more difficult will provide significant benefits in terms of businesses. The universe of the work consists of 530 people working in 9 hotels operating in Kocaeli, Kartepe. Therefore, according to the sample of calculation table, 345 people have formed. The "Sustainable Hotel Paradigm Scale" and the "Sustainability Applicability Scale" used for the data will be obtained from participants in the study. As a result of the analyzes made, it was determined that the

Özgün Araştırma Makalesi (Original Research Article)

Geliş/Received: 26.04 .2017

Kabul/Accepted: 17.01 .2018

DOI: http://dx.doi.org/10.17336/igusbd.308247

* Doktora Öğr., İstanbul Gelişim Üniversitesi, Sosyal Bilimler Enstitüsü, İşletme Programı, İstanbul, Türkiye, E-posta: nkonyalilar@hotmail.com ORCID ID https://orcid.org/0000-0002-7310-7779
\end{abstract}


age variability of employees is statistically effecting on ensuring sustainability, the environment, increasing in-service and external training. Additionally, a positive relationship was found between increasing education and absence of environmental pollution. It has been determined that there is a relationship between the encouragement of consumers in the area of environmental protection while meeting their needs and the prevention of environmental pollution.

Keywords: Sustainability, Sustainable Hotel, Ecological Balance, Environmental Responsibility, Tourism Businesses

\section{Giriș}

Çevreye duyarlı, müşteri memnuniyetini esas alan turizm işletmeleri, çalışanlarının vasıflı ve hizmetlerinin kaliteli olması durumunda varlıklarını sürdürebilmekte ve rekabette başarı sağlayabilmektedirler. Turizm sektörü, sürekli olarak önemli gelişmeler gösteren ve ülke ekonomilerinin lokomotifi haline gelen bir yapıya sahiptir. Çevreyle sürekli etkileşim içinde olan turizm endüstrisi, kültürel zenginliklerin korunması ile gelişebilecektir. Çevreye duyarlı tüketicilerin artması, çevre bilincinin yaygınlaşmasına ve turizm sektörünün de çevreye karşı duyarlılı̆̆ının artmasına neden olmaktadır. Sürdürülebilir bir turizm ve rekabet edebilir bir hizmet kalitesini sağlayabilmek için çalışanların eğitimi ve bireylerin çevre duyarlılığının artırılmasının önemi oldukça fazladır.

İşletmelerde, önce uygun olan personelin seçimi, işe alınma aşamasının tamamlanması ve sonrasında işin benimsemesinin akabinde personelin eğitilmesi aşamasına gelinmektedir. Eğitimi, personelin tanımlanmıș işi yapmak üzere nitelik ve bilgisini artırmak için uygulanan sistemlerin bütünü olarak tanımlamak mümkündür. İyi hazırlanmış bir eğitim programı, hem personele hem de işletmeye faydalar sağlamaktadır. Eğitim programı hazırlanırken, gerçek ihtiyacı karşılayabilmesi için, belirli görevde ve ilgili işkollarında çalışan personelin de katkısının sağlanması gereklidir. Personel gerçekten faydalanacağı eğitim programlarına katılmayı arzu etmektedir. Eğitim, personelin yapmakta olduğu işini daha iyi yapmasına ve üst unvana terfi ederek, kariyerini geliştirmesine imkân sağlamaktadır. Eğitim programlarının ve faaliyetlerin yoğun şekilde düzenlendiği, bilgi paylaşımlarının yapıldığı işletmeler, personel için bir çeşit okul görevi de görmektedir (Ertürk, 2006: 291).

Modern ve karmaşık bir iş çevresinde, çalışanların eğitimi ve gelişimi; değişimler gösteren iş dünyasında rekabet avantajı sağlayabilmek için ana konulardan birisidir. Eğitim ve kişisel gelişim, çalışanlar ve işletme için önemli faydalar sağlamaktadır (Falola and Osibanjo, 2014: 166).

"Sürdürülebilir Otel" denilen veya başka bir ifadeyle yeșil otel olarak adlandırılan kavram, daha az enerji ve su tüketen, $\mathrm{CO} 2$ emisyonları azaltılmış, küresel iklim değişikliği tehlikesine karşı bilinçli, gıda güvenliği, kuraklık ve çevre kirliliği bilinci ile doğa ile ilişkisini doğru tanımlamış, bu nedenle ekolojik 
ilkelere uygun çevre dostu yerel ve geri dönüştürülebilir malzemeler ile inşa edilmiş, toplum sağlığına önemli katkı sağlayan ve böylece yatırımcısının sosyal ve çevresel sorumluluğunu belgeleyen otel anlamına gelmektedir. "Sürdürülebilir Otel" kavramı, giderek daha fazla bilinirliği artarak yaygınlaşmaktadır. Gerek butik oteller gerekse de dünya çapında tanınmış otel zincirleri, otel tasarımı ve işletmesinde değişiklikler yapmışlardır. Sayıları giderek artan yeşil otellerden bir kısmı, bünyesinde hiçbir şekilde elektronik alet barındırmayı tercih etmezken, bazısı sadece müşteriler istediği zaman havlu ve çarşafları değiştirerek tasarruf sağlamaya çalışmaktadırlar. Ancak globalleşen dünyada turistik tesisler için en doğru çözüm tüm yeni teknolojileri kullanarak, tasarımdan planlamaya, uygulamadan malzemeye uzanan tüm aşamalarda ekolojik ilkelere uygun, doğa dostu uygulamaları temel alarak toplam karbon ayak izini ve su tüketimini azaltabilmek olmalıdır (Canbay, 2012: 49).

Sürdürülebilirlik, turizm sektöründe önemli konulardan birisidir. Uluslararası otel şirketleri sürdürülebilirliklerini artırabilmek için tüketicileri teşvik edici uygulamalar gerçekleştirmektedir (Upadhyay et al., 2013: 1). Turizm işletmelerinin tüketicilerinin memnuniyetini artıracak uygulamalar gerçekleştirmeleri, rekabet başarısı açısından vazgeçilemez bir husustur.

Çevre duyarlılığı, son yıllarda daha da yaygınlaşan bir kavram haline gelmiştir. Böylece işletmeler topluma karşı sorumluluklarını ifa etme fırsatı bulmuşlardır. Çevreye duyarlı olmak ve ekolojik ilkelerle uyumlu olmak, küçük ve orta boy işletmeler için beraberinde geniş olanaklar da getirmektedir. Burada dikkat edilmesi gereken nokta, işletmelerin çevre konusunda duyarlılığının gerçek olup olmadığı konusudur. Son dönemde sivil toplum kuruluşlarının da verdiği desteğin itici gücüyle kamuoyunun dikkatini çeken ve kuruluşlara çok fazla yol açabilen çevre duyarlılığı, sadece bir çevre projesinin desteklenmesi olarak algılanmamalıdır. $\mathrm{Bu}$ bağlamda, doğal çevreye karşı duyarlılığın artması, doğanın korunması ve yeniden kazanılması çabalarının en önemli unsurlarından biri kuşkusuz toplumun bilinçlenmesidir. Bu sebeple çevre konusunda resim, fotoğraf ya da kompozisyon gibi yarışmalar, etkinlikler düzenlenmesi faydalı olacaktır (Çavuşoğlu, 2015: 92).

Çevre, bütün canlı ve cansız varlıkların bulunduğu bir alanı kapsamaktadır. Yaşadığımız çevrede ihtiyaçların kaşınabilmesi için su, hava ve toprak gibi kaynaklara ihtiyaç olmaktadır. İnsan ihtiyaçlarının karşılanabilmesi sırasında bir takım bilinçsiz baskılar uygulamalar nedeniyle çevrede birçok olumsuzluk meydana gelebilmektedir. Çevrenin bozulmalar karşısında kendisini yenileme şansı olmadığı taktirde çevre kirliliği kendiliğinden ortaya çıkmaktadır. Örneğin; yeraltı sularının aşırı kullanılması, onların tamamen kaybedilmesine neden olabilecektir. Bu nedenlerle, çevre koruma konusunda farkındalık yaratılmasına ihtiyaç vardır. Çevremizi ulusal ve uluslararası seviyede korumak her bireyin görevi olabilmelidir (Contemporary: Erişim Tarihi: 16.07.2016). 
Turizm işletmeleri için tüketici kitlesi her geçen gün artmaktadır fakat küreselleşme, teknolojik gelişme ve artan rekabet, bu işletmeleri uluslararası turizm pazarındaki paylarını arttırmak için zorlu bir yarış içine sokmuştur. Bu yarışı kazanabilmek için tüketici davranışlarını ve bu davranışları etkileyen faktörleri belirlemek turizm işletmelerinin pazarlama faaliyetlerine ve satış arttırma çabalarına olumlu katkı yapacaktır. Tüketici davranışları hangi mal ve hizmetlerin satın alınacağı kimden, nasıl, nereden, ne zaman satın alınacağı ve satın alınıp alınmayacağına ilişkin bireylerin kararlarına ait süreçtir. $\mathrm{Bu}$ nedenle tüketici davranışlarını anlamak, turizm ürünlerini tüketicinin isteği doğrultusunda üretmeyi ve tüketiciye sunmayı sağlamaktadır. Turizm ürünlerini doğru ve kusursuz sunmak için tüketiciyi etkileyebilen nedenlerin neler olduğunu, ürün ve destinasyon tercihlerini hangi faktörlerin etkilediğini, satın alma şekli ve sebeplerini; diğer bir deyişle, tüketicilerin karar aşamalarını iyi analiz edebilmek gerekmektedir. Tüketicinin içinde bulunduğu durumla olmasını istediği durum arasında bir farklılık var ise ortaya sorun çıkıyor demektir. Sorunun istenen yönde sonuç verecek şekilde çözümü, karar verme sürecinin işleyişi ile gerçekleşir. Bu nedenle satın alma karar süreci, tüketicinin en yüksek fayda veya en üst verimi elde edeceği ürünü seçerken izleyeceği yol haritasını belirtmektedir (Demir ve Kozak, 2011: 19). Turizm sektörü yöneticilerinin, turizm tüketicilerini tüketim kararlarını etkileyen tercihlerini dikkate almadan başarılı olabilmeleri mümkün olamamaktadır. Yöneticilerin, tüketici davranışlarını dikkate alması gerekmektedir. Örneğin; tüketicilerin satın alma sebepleri, çeşitli promosyonlara karşı tüketicilerin tepkisinin izlenmesi gerekmektedir (Qırıc, 2011: 2).

Kalite kavramına, hizmet sektörü açısından bakıldığında belirsiz ve karmaşık kavram olduğu ifade edilebilir. Bunun sebebi, anlaşılma zorluğu, uygulanabilirlik, kontrol edebilme ve sürekliliği sağlama açısından karşılaşılan zorluklar olarak ifade edilebilir. Hizmet kalitesi, pek çok nedenden dolayı farklı anlaşılmaktadır. Hizmet sektöründe hizmetin kalitesi görecelidir. Hizmeti gören kişiden kişiye hatta hizmeti alan müşteriden müşteriye farklılıklar gösterebilmektedir. Farklılık, hizmetlerin mallara kıyasla standardize edilmesinin zor olması yüzünden oluşmaktadır. Kavramın bu kadar zor anlaşılır olmasının sonucunda ise değerlendirilmesi de aynı oranda kolay olmamaktadır (Kılış ve Eleren, 2009: 92).

Hizmet kalitesinde söz konusu olan beş temel boyut; a) fiziksel görünüm, donanım, b) güvenirlik, c) çalışanların güvencesi, d) empati, e) duyarlılık olarak sıralanabilir. İşletmelerin hizmet kalitesini sunabilmek için fiziksel görünümlerinin eksiksiz, güvenirliğin en üst seviyede, çalışanların tecrübeli, empatinin en üst seviyede ve tüketiciye karşı duyarlılığın en iyi şekilde olması gerekmektedir (Saghier and Nathan, 2013: 3).

\section{YÖNTEM}

Amaç; Sürdürülebilir oteller veya yeşil oteller; seyahat esnasında çevreye zarar vermeyen, çevreye karşı duyarlılığı yüksek, geleceğe önem veren 
ve bu gibi nedenlerle daha fazla ödemeye hazır, çevreye duyarlı turizm tüketicileri tarafından tercih edilen merkezler olarak tanımlanmaktadır. Çalışmanın amacı; sürdürülebilir otellerin sayısının artırılmasını, çevreye duyarlığın artmasını, ekonominin gelișmesini, ilgili işletmelerin karlılığının artmasını, alınacak sertifikalarla sürdürülebilir turizm işletmelerinin çoğalmasını ve çevreye duyarlı ziyaretçilerin rahatça ayarlanabilmesini sağlayacak tedbirlerin neler olduğunu tespit etmek, verilecek eğitimlerin yararlarını izah etmek ve sürdürülebilir otel yapılanmasını sağlayacak öneriler sunabilmektir.

Personelin çevre farkındalığını artırması ve eğitimi, otel çalışanlarının yeşil otel anlayışını benimsemesini artırabilecektir. Yapılacak toplantılar ve gerçekleştirilecek geri beslemeler çalışanların farkındalığını artırabilecektir. Ayrıca, çalışanların motive edilmesi, teşvik edilmesi ve ödüllendirilmesi hizmet kalitesini artırabilecektir.

Evren ve örneklem; bu araştırmada evren büyüklüklerine göre örneklem hacmi, Tablo-1'e bakılarak oluşturulmuştur. Çalışmanın evrenini Kocaeli Kartepe'de faaliyet gösteren 9 otelde çalışan 530 kişi oluşturmaktadır. Tablo-1'e bakıldığında 1000 kişiden oluşmakta olan ana kütle büyüklüğünde, \%5 güvenlirlikte ve 244 kişinin yeterli olabileceği görülmektedir. Dolayısıyla, örneklem hesaplama tablosuna göre 345 kişi oluşturmuştur.

Tablo-1 Örneklem Büyüklükleri (Yazıcıoğlu ve Erdoğan, 2004: 50)

\begin{tabular}{|l|l|l|l|l|l|l|l|l|l|}
\hline \multirow{2}{*}{$\begin{array}{l}\text { Evren } \\
\text { Büyüklüğ̈̈ }\end{array}$} & \multicolumn{9}{|l}{$\begin{array}{l}+0.03 \\
(\mathrm{~d})\end{array}$} \\
\cline { 2 - 12 } & $\begin{array}{l}\mathrm{p}=0.5 \\
\mathrm{q}=0.5\end{array}$ & $\begin{array}{l}\mathrm{p}=0.8 \\
\mathrm{q}=0.2\end{array}$ & $\begin{array}{l}\mathrm{p}=0.3 \\
\mathrm{q}=0.7\end{array}$ & $\begin{array}{l}\mathrm{p}=0.5 \\
\mathrm{q}=0.5\end{array}$ & $\begin{array}{l}\mathrm{p}=0.8 \\
\mathrm{q}=0.2\end{array}$ & $\begin{array}{l}\mathrm{p}=0.3 \\
\mathrm{q}=0.7\end{array}$ & $\begin{array}{l}\mathrm{p}=0.5 \\
\mathrm{q}=0.5\end{array}$ & $\begin{array}{l}\mathrm{p}=0.8 \\
\mathrm{q}=0.2\end{array}$ & $\begin{array}{l}\mathrm{p}=0.3 \\
\mathrm{q}=0.7\end{array}$ \\
\hline 100 & 92 & 87 & 90 & 80 & 71 & 77 & 49 & 38 & 45 \\
\hline 500 & 341 & 289 & 321 & 217 & 165 & 196 & 81 & 55 & 70 \\
\hline 750 & 441 & 358 & 409 & 254 & 185 & 226 & 85 & 57 & 73 \\
\hline 1000 & 516 & 406 & 473 & 278 & 198 & 244 & 88 & 58 & 75 \\
\hline 2500 & 748 & 537 & 660 & 333 & 224 & 286 & 93 & 60 & 78 \\
\hline 5000 & 880 & 601 & 760 & 357 & 234 & 303 & 94 & 61 & 79 \\
\hline 10000 & 964 & 639 & 823 & 370 & 240 & 313 & 95 & 61 & 80 \\
\hline 25000 & 1023 & 665 & 865 & 378 & 244 & 319 & 96 & 61 & 80 \\
\hline 50000 & 1045 & 674 & 881 & 381 & 245 & 321 & 96 & 61 & 81 \\
\hline 100000 & 1056 & 678 & 888 & 383 & 245 & 322 & 96 & 61 & 81 \\
\hline 1000000 & 1066 & 682 & 896 & 384 & 246 & 323 & 96 & 61 & 81 \\
\hline $\begin{array}{l}100 \\
\text { milyon }\end{array}$ & 1067 & 683 & 896 & 384 & 245 & 323 & 96 & 61 & 81 \\
\hline
\end{tabular}




\section{Hipotezler:}

Hipotez H0.1: Çalışanların yaş değişkeninin, sürdürebilirliğin sağlanmasında çevre konusunda hizmet içi ve dışardan eğitimlerin artırılması üzerinde istatiksel olarak etkisi yoktur.

Hipotez H0.2: Çalışanların yaş değişkeninin, tüketicilerin ihtiyaçlarını karşılarken çevre kirliliğine neden olmamasına istatiksel olarak etkisi yoktur.

Hipotez H0.3: Çalışanların yaş değişkeninin, insanların tüketim alışkanlıklarının çevreye karşı duyarlılığa özendirilmesine istatiksel olarak etkisi yoktur.

Hipotez H0.4: Sürdürebilirliğin sağlanmasında çevre konusunda hizmet içi ve dışardan eğitimlerin artırılması ile diğer faktörler arasında istatistiksel anlamda bir ilişki yoktur.

Hipotez H0.5: Tüketicilerin ihtiyaçlarını karşılarken çevre kirliliğine neden olmaması faktörünün diğer faktörler üzerinde istatiksel olarak etkisi yoktur.

Verilerinin Elde Edilmesi: $\mathrm{Bu}$ çalışmanın teorik bölümünde, sürdürülebilirlik, çalışanların bilgilendirilmesi, çevre duyarlılığı vb. ilgili hususlar ele alınmıştır. Çalışmanın alan araştırması kısmında, alan uygulamalı, verilerin ankete elde edildiği, niceliksel yöntem izlenmiştir. Hazırlanacak anket ile katılımcıların verdikleri cevaplar vasıtasıyla veriler elde edilecektir. Anketin hazırlanmasında beşli likert yöntemine başvurulmuştur.

Ölçekler: "Sürdürülebilir Otel Paradigması Ölçeği" (Dunlap et al., 2000: 433) ve "Sürdürülebilirliğin Uygulanabilirliği Ölçeği” (Güven ve Aydoğdu, 2012: 201-202) yardımı ile katılımcılardan çalışmanın verileri elde edilmiştir.

Verilerin analizi: Araştırma verilerinin analizinde; Anova analizi, Kaiser-Meyer-Olkin Değerlerinin hesaplanması (KMO) testi, Cronbach's Alpha Katsayısının Analizi, Faktör Analizi, Regresyon Analizi gibi analizlerden yararlanılmıştır. Hipotezleri sınamak için veriler SPSS 21 programında istatistiksel analizler yardımıyla değerlendirilmiştir.

\section{Araştırma Ölçeklerinin Genel Güvenilirlik Analizi}

Tablo-2 Güvenilirlik Analizi Tablosu

\begin{tabular}{|c|c|}
\hline Cronbach's Alpha Katsayısı & Sayı \\
\hline, 697 & 11 \\
\hline
\end{tabular}

Cronbach's Alpha katsayısı yapılan çalışmadaki soruların güvenilirliliğini ölçmektedir ve sıfır ile bir arasında değerler alır. Cronbach's Alpha katsayısı 0 ve 0'a yakın değerler aldığında çalışmanın güvenilirliğinin az olduğu, 1'e yaklaştıkça güvenilirliğin arttığını ve yüksek olduğu kabul edilmektedir. Yapılan araștırmanın güvenilirlik katsayısı 0,697 olarak hesaplanmış ve yüksek bir değer olduğu görülmüştür. Bu yüzden çalışma güvenilirdir kararı verilir. 
Tablo-3 Demografik Değişkenlerin Frekans Analizleri

\begin{tabular}{|l|l|c|c|}
\hline & & Frekans & Yüzde \\
\hline \multirow{4}{*}{ Öğrenim Durumu } & İlköğretim & 208 & 60,5 \\
\cline { 2 - 4 } & Üniversite & 24 & 7,0 \\
\cline { 2 - 4 } & Lisans & 95 & 27,6 \\
\cline { 2 - 4 } & Yüksek Lisans & 17 & 4,9 \\
\hline \multirow{5}{*}{ Yaş } & $20-30$ Yaş & 143 & 41,6 \\
\cline { 2 - 4 } & $31-42$ Yaş & 63 & 18,3 \\
\cline { 2 - 4 } & 43-54 Yaş & 87 & 25,3 \\
\cline { 2 - 4 } & 55 ve Üzeri & 50 & 14,5 \\
\hline \multirow{5}{*}{ Göreviniz } & Muhasebeci & 31 & 9,0 \\
\cline { 2 - 4 } & Yönetici & 26 & 7,6 \\
\cline { 2 - 4 } & Resepsiyon & 55 & 16,0 \\
\cline { 2 - 4 } & Görevlisi & 63 & 18,3 \\
\cline { 2 - 4 } & Ofis Memuru & 169 & 49,1 \\
\cline { 2 - 4 } & Temzilik Elemanı & & \\
\hline
\end{tabular}

Yapılan çalışmaya 208 ilkokul $(\% 60,5)$, 24 üniversite $(\% 7,0)$, 95 lisans $(\% 27,6)$ ve 17 yüksek lisans $(\% 4,9)$ eğitimi almış kişi katılmıştır. Çalışmada eğitim durumu dağılımının büyük çoğunluğunun ilköğretim mezunu olduğu görülmektedir.

Katılımcıların 143'ü $(\% 41,6)$ 20-30 yaş aralığında, 63'ü $(\% 18,3)$ 31-42 Yaş Aralığında, 87'si (\%25,3) 43-54 yaş aralığında ve 50 kişi $(\% 14,5)$ ise 55 yaş ve üzeridir. Katılımcıların yaş değişkenine göre dağılımları incelendiğinde büyük çoğunluğunun genç ve orta yaş grubundan oluştuğu görülmektedir.

Katılımcıların görevlerine göre dağılımlarına bakıldığı zaman 26 yönetici $(\% 7,6), 31$ muhasebeci $(\% 9), 55$ resepsiyon görevlisi $(\% 16,0), 169$ temizlik görevlisi $(\% 49,1)$ ve 63 kişinin $(\% 18,3)$ ise ofis memuru olarak hizmet verdiği görülmektedir. Çalışanların yaklaşık yarısının temizlik elemanı olarak hizmet verdiği görülmektedir. 


\section{Faktör Analizi}

\subsection{Kaise-Mayer-Olkin ve Bartlett Testi}

Tablo-4 Kaiser-Meyer-Olkin ve Bartlett's Test

\begin{tabular}{|l|l|l|}
\hline \multicolumn{2}{|l|}{ KMO and Bartlett's Testi } \\
\hline \multicolumn{2}{|l|}{ Kaiser-Meyer-Olkin Ölçüm Değeri } & $\mathbf{8 9 7}$ \\
\hline \multirow{3}{*}{ Bartlett's Testi } & Ki-Kare Değeri & 1373,697 \\
\cline { 2 - 3 } & Df Değeri & 55 \\
\cline { 2 - 3 } & Sigma Değeri & $\mathbf{, 0 0 0}$ \\
\hline
\end{tabular}

Faktör analizi, birbiriyle ilişkili çok sayıda değişkeni bir araya getirerek az sayıda kavramsal olarak anlamlı yeni değişkenler (faktörler, boyutlar) bulmayı, keşfetmeyi amaçlayan çok değişkenli bir istatistiktir. Ancak her veri setine faktör analizi uygulanmaz. Faktör analizi yapmak için Faktör analizine uygunluğu test eden KMO ölçüm değeri ve bartlett testi incelenmelidir. KMO ölçüm değeri 0 ile 1 arasında değerler alır. Bu değer 1' yaklaştıkça değişkenler arasındaki ilişkinin arttığı ve faktör analizi yapmanın anlamlı olduğu kararı verilir. Bu değer 1'e yaklaştıkça sigma değeri küçülür ve bir yerden sonra 0 eşitlenir. Sigma değeri 0,05 değeri olan alfa değerinden küçük olmalıdır. Yapılan çalışmada elimizdeli veriler için yapılan KMO barlett testinin sonucunda elde edilen ölçüm değeri 0,897 olarak hesaplamıștır. Aynı zamanda sigma değeride $\mathbf{0 , 0 0 0}$ olarak hesaplanmıştır. $\mathrm{Bu}$ durumda veriler üzerinde faktör analizi uygulamanın uygun olduğuna karar verilir.

\subsection{Faktör Sayısının Tespiti}

Faktör sayısının tespiti için öz değere analiz yapılacaktır.

Tablo-5 Öz Değer Analizi Tablosu

\begin{tabular}{|c|c|c|c|c|c|c|c|c|c|}
\hline & \multicolumn{3}{|c|}{ Genel Öz Değerler } & \multicolumn{3}{|c|}{ Öz Değer Çıkarımları } & \multicolumn{3}{|c|}{$\begin{array}{c}\text { Döndürülmüş Öz Değer } \\
\text { Çıkarımları }\end{array}$} \\
\hline & 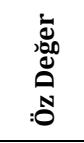 & 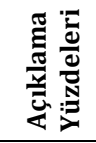 & 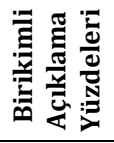 & 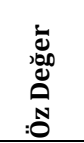 & 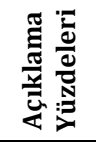 & 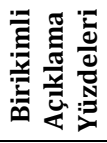 & 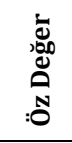 & 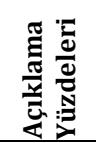 & 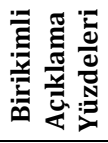 \\
\hline 1 & 4,358 & 39,615 & 39,615 & 4,358 & 39,615 & 39,615 & 4,284 & 38,943 & 38,943 \\
\hline 2 & 2,158 & 20,525 & 60,140 & 2,158 & 20,525 & 60,140 & 1,231 & 21,189 & 60,131 \\
\hline 3 & 1,011 & 9,188 & 69,328 & 1,011 & 9,188 & 69,328 & 1,012 & 9,197 & 69,328 \\
\hline 4 & 971 & 8,828 & 68,156 & & & & & & \\
\hline 5 & ,834 & 7,586 & 75,742 & & & & & & \\
\hline
\end{tabular}




\begin{tabular}{|c|c|c|c|l|l|l|l|l|l|}
\hline 6 &, 796 & 7,240 & 82,983 & & & & & & \\
\hline 7 &, 548 & 4,978 & 87,960 & & & & & & \\
\hline 8 &, 501 & 4,552 & 92,512 & & & & & & \\
\hline 9 &, 365 & 3,318 & 95,830 & & & & & & \\
\hline 10 &, 240 & 2,185 & 98,015 & & & & & & \\
\hline 11 &, 218 & 1,985 & 100,000 & & & & & & \\
\hline
\end{tabular}

Faktör analizi uygulanan veri seti için faktör sayısı belirlenirken öz değerler incelenir. Öz değerleri 1'den büyük olan değerlerin sayısı bize faktör sayımızı verecektir. Tabloda öz değerler incelendiğinde 3 değerin 1'den büyük olduğu görülmektedir. Bu yüzden faktör sayısı 3 olarak belirlenir. Birinci faktör tek başına çalışmanın yüzde 38,943 ' ünü , İkinci faktör tek başına 21,189'unu ve üçüncü faktör tek başına 9,197'sini açıklamaktadır. Üç faktör birlikte anketin yüzde 69,328'ini açlklamaktadır.

\subsection{Faktör Analizi}

Tablo-6 Faktör Analizi Tablosu

\begin{tabular}{|c|c|c|c|}
\hline Sorular & $\begin{array}{c}\text { Sürdürebilirliğin } \\
\text { Sağlanmasında Çevre } \\
\text { Konusunda Hizmet İçi ve } \\
\text { Dışardan Eğitimlerin } \\
\text { Artırıması }\end{array}$ & $\begin{array}{c}\text { Tüketicilerin } \\
\text { İhtiyaçlarını } \\
\text { Karşılarken Çevre } \\
\text { Kirliliğine Neden } \\
\text { Olmama }\end{array}$ & $\begin{array}{c}\text { Ínsanların Tüketim } \\
\text { Alışkanlıklarının } \\
\text { Çevreye Karşı Duyarlı } \\
\text { Olmaya Özendirilmesi }\end{array}$ \\
\hline S5 & $\mathbf{7 1 6}$ &, 138 &, 026 \\
\hline S6 &, 242 & $\mathbf{, 5 2 8}$ &,- 072 \\
\hline S7 &, 300 & $\mathbf{, 7 1 1}$ &, 028 \\
\hline S8 & $\mathbf{, 6 9 4}$ &, 326 &,- 019 \\
\hline S9 & $\mathbf{8 7 5}$ &, 019 &, 060 \\
\hline S10 & $\mathbf{8 7 0}$ &, 093 &, 000 \\
\hline S11 &, 117 &,- 477 &, 026 \\
\hline S12 &,- 341 &, $\mathbf{5 1 7}$ &, 122 \\
\hline S13 & $\mathbf{8 1 8}$ &,- 061 &,- 074 \\
\hline S14 & $\mathbf{8 8 1}$ &, 042 &, 022 \\
\hline S15 &, 010 &,- 031 &, $\mathbf{9 9 0}$ \\
\hline
\end{tabular}

Faktör sayısı 3 olarak belirlendikten sonra değişkenlerin faktörler üzerindeki dağılımları yapılmalıdır. Tabloda değişkenlerin faktörler üzerindeki yük dağılımları görülmektedir. Değişkenin en fazla yükü hangi faktörde ise değişken o faktöre aittir. 


\subsection{Faktörlerin Anket Sorularına Dağılımı}

Tablo-7 Çalıșan Performansı Anket Sorularının Faktörlere Dağılımı Tablosu

\begin{tabular}{|l|l|}
\hline Faktörler & Döndürülmüş Faktör Analizi \\
\hline $\begin{array}{l}\text { F1. Sürdürebilirliğin Sağlanmasında Çevre Konusunda } \\
\text { Hizmet İçi ve Dışardan Eğitimlerin Artırılması }\end{array}$ & $\mathrm{S} 5, \mathrm{~S} 8, \mathrm{~S} 9, \mathrm{~S} 10, \mathrm{~S} 13, \mathrm{~S} 14$ \\
\hline $\begin{array}{l}\text { F2. Tüketicilerin İhtiyaçlarını Karşılarken Çevre Kirliliğine } \\
\text { Neden Olmamak }\end{array}$ & $\mathrm{S6}, \mathrm{S} 7, \mathrm{~S} 11, \mathrm{~S} 12$ \\
\hline $\begin{array}{l}\text { F3. İnsanların Tüketim Alışkanlıklarının Çevreye Karşı } \\
\text { Duyarlı Olmaya Özendirilmesi }\end{array}$ & $\mathrm{S} 15$ \\
\hline
\end{tabular}

Tablo-7 incelendiğinde, döndürülmüş faktör analizi sonucunda, anket sorularının belirlenen 4 faktöre dengeli bir şekilde dağıldığı gözlemlenmektedir. Anket sorularının, faktörlere dağılımı yukarıdaki tabloda gösterilmiştir.

\subsection{Ki-Kare Testi}

Tablo-8 Normallik Testi Tablosu

\begin{tabular}{|c|c|c|c|c|c|c|}
\hline & \multicolumn{3}{|c|}{$\begin{array}{l}\text { Kolmogorov- } \\
\text { Smirnov }^{\mathrm{a}}\end{array}$} & \multicolumn{3}{|c|}{ Shapiro-Wilk } \\
\hline & 窇 & 离 & 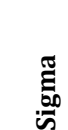 & 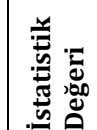 & 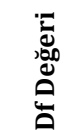 & 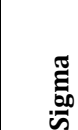 \\
\hline $\begin{array}{l}\text { Sürdürebilirliğin Sağlanmasında Çevre } \\
\text { Konusunda Hizmet İçi ve Dışardan } \\
\text { Eğitimlerin Artırılması }\end{array}$ & 184 & 344 & ,000 & 875 & 344 & ,000 \\
\hline $\begin{array}{l}\text { Tüketicilerin İhtiyaçlarını Karşılarken Çevre } \\
\text { Kirliliğine Neden Olmamak }\end{array}$ & 091 & 344 & ,000 & ,983 & 344 & ,001 \\
\hline $\begin{array}{l}\text { İnsanların Tüketim Alışkanlıklarının Çevreye } \\
\text { Karşı Duyarlılığa Özendirilmesi }\end{array}$ & ,225 & 344 & ,000 & ,842 & 344 & ,000 \\
\hline
\end{tabular}

Normallik testi verilerin normal dağılıma uyum sağlayıp sağmadığını ölçmek için yapılır. Normallik varsayımı parametrik testlerin başında gelmektedir. 0 yüzden uygulanacak teste karar vermeden önce varsayımlar incelenmelidir. Yukarıdaki tabloda tüm faktörler için Sigma değeri 0,000 olarak hesaplanmış ve bu değerler alfa değerinden $(0,05)$ daha küçük olduğu görülmüştür. Bu yüzden ilgili analizlerin yapılmasına karar verilir. 


\subsection{1. Çalışanların Yaş Durumu ile Araştırma Faktörlerinin Ki-Kare} Testi

Tablo-9 Çalıșanların Yaş Durumu ile Araștırma Faktörlerinin Ki-Kare Testi

\begin{tabular}{|l|l|l|l|}
\hline Faktörler & Ki- Kare & $\begin{array}{l}\text { Df } \\
\text { Değeri }\end{array}$ & Sigma \\
\hline $\begin{array}{l}\text { Sürdürebilirliğin Sağlanmasında Çevre Konusunda } \\
\text { Hizmet İçi ve Dışardan Eğitimlerin Artırılması }\end{array}$ & $\mathbf{9 , 4 9 1}$ & 3 &, $\mathbf{0 3 8}$ \\
\hline $\begin{array}{l}\text { Tüketicilerin İhtiyaçlarını Karşılarken Çevre Kirliliğine } \\
\text { Neden Olmamak }\end{array}$ & 2,887 & 3 &, 409 \\
\hline $\begin{array}{l}\text { İnsanların Tüketim Alıșkanlıklarının Çevreye Karşı } \\
\text { Duyarlılığa Özendirilmesi }\end{array}$ & 3,230 & 3 &, 358 \\
\hline
\end{tabular}

Hipotezler;

Hipotez H0.1: Çalışanların yaş değişkeninin, sürdürebilirliğin sağlanmasında çevre konusunda hizmet içi ve dışardan eğitimlerin artırılması üzerinde istatiksel olarak etkisi yoktur.

Hipotez H0.2: Çalışanların yaş değişkeninin, tüketicilerin ihtiyaçlarını karşılarken çevre kirliliğine neden olmamasına istatiksel olarak etkisi yoktur.

Hipotez H0.3: Çalışanların yaş değişkeninin, insanların tüketim alışkanlıklarının çevreye karşı duyarlılığa özendirilmesine istatiksel olarak etkisi yoktur.

Çalışanların görevlerine göre farklılıklar incelenmiş ve gerekli hesaplamalar tablo-8'de verilmiştir. $\mathrm{Bu}$ tablodaki Sigma değerleri alfa değerinden $(0,05)$ küçük olursa hipotez reddedilir. Sürdürebilirliğin sağlanmasında çevre konusunda hizmet içi ve dışardan eğitimlerin artırılması, tüketicilerin ihtiyaçlarını karşılarken çevre kirliliğine neden olmaması ve insanların tüketim alışkanlıklarının çevreye karşı duyarlılığa özendirilmesi faktörlerinin Sigma değerleri sırası ile $0,038,0.409$ ve 0,358 olarak hesaplanmıştır ve bu değerlerden Sürdürebilirliğin sağlanmasında çevre konusunda hizmet içi ve dışardan eğitimlerin artırılması faktörü için olan sigma değeri alfa değerinden $(0,05)$ küçüktür $(\mathrm{p}=0,38<0,05)$. Bu yüzden $\mathrm{H} 0$ hipotezi reddedilir, H1 kabul edilir ve çalışanların yaş değişkeninin sürdürebilirliğin sağlanmasında çevre konusunda hizmet içi ve dışardan eğitimlerin artırılması faktörü üzerinde etkisi vardır. 


\subsection{Regresyon Analizi}

\subsubsection{Sürdürebilirliğin Sağlanmasında Çevre Konusunda Hizmet İçi ve Dışardan Eğitimlerin Artırılması ile Diğer Faktörlerin Karşılaştırılması}

Tablo-10 Regresyon Analizi Anlamlılık Tablosu

\begin{tabular}{|l|c|c|c|c|c|}
\hline \multicolumn{1}{|c|}{ Model } & $\begin{array}{c}\text { Kareler } \\
\text { Toplamı }\end{array}$ & Df Değeri & $\begin{array}{c}\text { Kareler } \\
\text { Ortalaması }\end{array}$ & F & Sigma \\
\hline Regresyon & 5,474 & 2 & 2,737 & 2,254 &, 037 \\
\hline Artık Değer & 414,123 & 341 & 1,214 & & \\
\hline Toplam & 419,598 & 343 & & & \\
\hline
\end{tabular}

Regresyon Analizi Anlamlılık Tablosu aralarındaki ilişkileri incelediğimiz değişkenler üzerinde regresyon analizi uygulamanın anlamlı olup olmadığını inceler. Regresyon analizi yapıp yapmamaya karar verirken ise sigma değerini kullanır. Eğer Sigma değeri alfa değeri olan 0,05'ten değerinden büyük olursa regresyon modeli anlamsız bulunmuştur demektir. Sürdürebilirliğin sağlanmasında çevre konusunda hizmet içi ve dışardan eğitimlerin artırılması faktörü için gerekli hesaplamalar yapılmış ve Sigma değeri 0,037 olarak hesaplanmıştır. Bu durumda değişkenler üzerinde regresyon analizi uygulamak anlamlı bulunmuştur.

Tablo-11 Sürdürebilirliğin Sağlanmasında Çevre Konusunda Hizmet İçi ve Dışardan Eğitimlerin Artırılması ile Diğer Faktörlerin Regresyon Analizi Katsayı Tablosu

\begin{tabular}{|l|l|l|l|l|l|}
\hline \multirow{2}{*}{ Model } & \multicolumn{2}{|l|}{$\begin{array}{l}\text { Standart Olmayan } \\
\text { Katsayılar }\end{array}$} & $\begin{array}{l}\text { Standart } \\
\text { Değerler }\end{array}$ & T-Değeri & Sigma \\
\cline { 2 - 5 } & B & $\begin{array}{l}\text { Standart } \\
\text { Hata }\end{array}$ & Beta & & \\
\hline & 2,329 &, 379 & & 6,148 &, $\mathbf{0 0 0}$ \\
\hline $\begin{array}{l}\text { Tüketicilerin İhtiyaçlarını } \\
\text { Karşılarken Çevre Kirliliğine } \\
\text { Neden Olmamak }\end{array}$ &, 177 &, 084 &, 114 & 2,123 &, $\mathbf{0 3 4}$ \\
\hline $\begin{array}{l}\text { İnsanların Tüketim } \\
\text { Alışkanlıklarının Çevreye Karşı } \\
\text { Duyarlı Olmaya Özendirilmesi }\end{array}$ &,- 002 &, 061 &,- 001 &,- 025 &, 980 \\
\hline
\end{tabular}

Hipotez H0.4: Sürdürebilirliğin sağlanmasında çevre konusunda hizmet içi ve dışardan eğitimlerin artırılması ile diğer faktörler arasında istatistiksel anlam da bir ilişki yoktur.

Regresyon tablosu incelendiğinde anlamlı bulunan katsayılar ile regresyon denklemi oluşturulmalıdır. Anlamlı bulunan katsayılara Sigma değeri yardımı ile karar verilmektedir. Bu değer alfa değerinden $(0,05)$ küçük olursa regresyon modeli için anlamlı bir değişken olduğuna karar verilir. Yukarıdaki regresyon tablosunda sürdürebilirliğin sağlanmasında çevre konusunda hizmet 
içi ve dışardan eğitimlerin artırılması ile diğer faktörler arasındaki ilişki incelenmiş ve sürdürebilirliğin sağlanmasında çevre konusunda hizmet içi ve dışardan eğitimlerin artırılması ile tüketicilerin ihtiyaçlarını karşılarken çevre kirliliğine neden olmaması arasındaki ilişki anlamlı bulunmuştur. Regresyon denklemi ise şu şekilde yazılır; sürdürebilirliğin sağlanmasında çevre konusunda hizmet içi ve dişardan eğitimlerin artırılması $=2,329+0,177$ tüketicilerin ihtiyaçlarını karşılarken çevre kirliliğine neden olmaması.

Burada, tüketicilerin ihtiyaçlarını karşılarken çevre kirliliğine neden olmaması 1 birim arttı̆̆ı zaman, sürdürebilirliğin sağlanmasında çevre konusunda hizmet içi ve dışardan eğitimlerin artırılması faktörü 0,177 birim artacaktır. Tüketicilerin ihtiyaçlarını karşılarken çevre kirliliğine neden olmaması faktörü; sürdürebilirliğin sağlanmasında çevre konusunda hizmet içi ve dışardan eğitimlerin artırılması faktörünü yüzde 17,7 oranında etkilemektedir ve aralarında pozitif yönlü bir ilişki vardır.

\subsubsection{Tüketicilerin İhtiyaçlarını Karşılarken Çevre Kirliliğine Neden Olmaması ile Diğer Faktörler Arasındaki Regresyon Analizi}

Tablo-12 Regresyon Analizi Anlamlılık Tablosu

\begin{tabular}{|l|c|c|c|c|c|}
\hline Model & $\begin{array}{c}\text { Kareler } \\
\text { Toplamı }\end{array}$ & Df Değeri & $\begin{array}{c}\text { Kareler } \\
\text { Ortalaması }\end{array}$ & F & Sigma \\
\hline Regresyon & 2,286 & 2 & 1,143 & 4,272 &, $\mathbf{0 4 5}$ \\
\hline Artık Değer & 171,505 & 341 &, 251 & & \\
\hline Toplam & 173,791 & 343 & & & \\
\hline
\end{tabular}

Tablo-12 temelde bağımlı değişken ile bağımsız değişkenler arasında regresyon analizi yapmanın anlamlı olup olmadığını ölçer. Bu durumda Sigma değerine göre karar verilir. Eğer Sigma değeri alfa değerinden büyük olursa regresyon modeli anlamsız bulunmaktadır. Tüketicilerin ihtiyaçlarını karşılarken çevre kirliliğine neden olmama faktörü için ölçüm ve hesaplamalar yukarıdaki tabloda verilmiştir. Sigma değeri 0,045 olarak hesaplanmıştır. Bu durumda regresyon modeli çıkarmak anlamlı bulunmuştur.

Tablo-13 Tüketicilerin İhtiyaçlarını Karşılarken Çevre Kirliliğine Neden Olmaması ile Diğer Faktörlerin Regresyon Analizi Katsayı Tablosu

\begin{tabular}{|l|l|l|l|l|}
\hline Model & Standart Olmayan Katsayılar & Standart Katsayılar & T-Değeri & Sigma \\
\cline { 1 - 3 } & Standart Hata & Beta & \\
\hline $\begin{array}{l}\text { (Constant) } \\
\text { Sürdürebilirliğin Sağlanmasında Çevre } \\
\text { Konusunda Hizmet İçi ve Dışardan } \\
\text { Eğitimlerin Artırılması }\end{array}$ & $\mathbf{3 , 2 4 6}$ & $\mathbf{1 8 7}$ & \\
\hline $\begin{array}{l}\text { Insanların Tüketim Alışkanlıklarının } \\
\text { Çevreye Karşı Duyarlılığa Özendirilmesi }\end{array}$ &, $\mathbf{0 0 8}$ &, 035 &, 114 \\
\hline
\end{tabular}


Hipotez H0.5: Tüketicilerin ihtiyaçlarını karşılarken çevre kirliliğine neden olmaması faktörünün diğer faktörler üzerinde istatiksel olarak etkisi yoktur.

Regresyon tablosu incelendiğinde anlamlı bulunan katsayllar ile regresyon denklemi oluşturulmalıdır. Anlamlı bulunan katsayılara Sigma değeri yardımı ile karar verilmektedir. Bu değer alfa değerinden $(0,05)$ küçük olursa regresyon modeli için anlamlı bir değişken olduğuna karar verilir. Regresyon tablosunda, insanların tüketim alışkanlıklarının çevreye karşı duyarlılığa özendirilmesi ile tüketicilerin ihtiyaçlarını karşılarken çevre kirliliğine neden olmaması faktörleri arasındaki ilişki anlamlı bulunmuştur. Regresyon denklemi ise şu şekilde yazılır; tüketicilerin ihtiyaçlarını karşılarken çevre kirliliğine neden olunmaması $=3,246+0,008$ sürdürebilirliğin sağlanmasında çevre konusunda hizmet içi ve dışardan eğitimlerin artırılması,

$\mathrm{Bu}$ durumda; sürdürebilirliğin sağlanmasında çevre konusunda hizmet içi ve dışardan eğitimlerin artırılması 1 birim arttığı zaman, tüketicilerin ihtiyaçlarını karşılarken çevre kirliliğine neden olmaması faktörü 0,008 birim artacaktır. İnsanların tüketim alışkanlıklarının çevreye karşı duyarlılığa özendirilmesi, tüketicilerin ihtiyaçlarını karşılarken çevre kirliliğine neden olmamasını yüzde 8 oranında etkilemektedir.

\subsection{3. İnsanların Tüketim Alışkanlıklarının Çevreye Karşı Duyarlılığa Özendirilmesi ile Diğer Faktörler Arasındaki Regresyon Analizi}

Tablo-14 Regresyon Analizi Anlamlılık Tablosu

\begin{tabular}{|l|c|c|c|c|c|}
\hline & $\begin{array}{c}\text { Kareler } \\
\text { Toplamı }\end{array}$ & Df Değeri & $\begin{array}{c}\text { Kareler } \\
\text { Ortalaması }\end{array}$ & F & Sigma \\
\hline Regresyon &, 035 & 2 &, 018 &, 018 &, $982^{\mathrm{b}}$ \\
\hline Artık Değer & 328,197 & 341 &, 962 & & \\
\hline Total & 328,233 & 343 & & & \\
\hline
\end{tabular}

Yukarıdaki tablo temelde bağımlı değişken ile bağımsız değişkenler arasında regresyon analizi yapmanın anlamlı olup olmadığını ölçer. $\mathrm{Bu}$ durumda Sigma değerine göre karar verilir. Eğer Sigma değeri alfa değerinden büyük olursa regresyon modeli anlamsız bulunmaktadır. İnsanların tüketim alışkanlıklarının çevreye karşı duyarlılığa özendirilmesi faktörü için ölçüm ve hesaplamalar yukarıdaki tabloda verilmiștir. Sigma değeri 0,982 olarak hesaplanmıştır. Bu durumda regresyon modeli çıkarmak anlamlı bulunmamış ve çok yüksek bir sigma değeri ile reddedilmiştir.

\section{SONUÇ ve ÖNERILER}

Çalışmada eğitim durumu dağılımının büyük çoğunluğunun ilköğretim mezunu olduğu $(208$ kişi \%60,5) tespit edilmiştir. İşletmenin çalışanların 
kariyerlerini yükseltecek teşvikler uygulaması çalışanların verimliliği açısından önemli yararlar sağlayabilecektir.

Çalışanların yaklaşık yarısının temizlik elemanı olarak hizmet verdiği (169 kişi, \%49,1) tespit edilmiştir. İşletmelerin hizmet kalitesi ve verimliliğinin artırılması için yönetici, resepsiyon vb. görev tütündeki elemanların artırılmasının yararı olabilecektir.

Yaş değişkeni ile sürdürebilirliğin sağlanmasında çevre konusunda hizmet içi ve dışardan eğitimlerin artırılması arasında ilişki bulunmuştur. İşletmelerin çalışanların yaşını dikkate alan çevre eğitimleri vermesi daha yararlı olabilecektir.

Tüketicilerin ihtiyaçlarını karşılarken çevre kirliliğine neden olmaması ile sürdürebilirliğin sağlanmasında çevre konusunda hizmet içi ve dışardan eğitimlerin artırılması arasında pozitif yönlü bir ilişki bulunmuştur. Dolayısıyla işletmeler, tüketicilerin ihtiyaçlarını karşılarken çevre kirliliğine neden olmamalı ve sürdürebilirlik için çevre konusunda eğitimlerini artırmaları yararlı olacaktır.

Çevre duyarlılığına özendirme ile tüketicilerin ihtiyaçlarını karşılarken çevre kirliliğine neden olmaması arasında ilişki bulunmuştur. Bu durumda, tüketicilerin ihtiyaçlarını karşılarken, çevreye duyarlı ürünlerin sunulması, tanıtılması, fiyat indirimleri uygulanması veya ödüller verilmesi sürdürülebilir otelcilik ve temiz bir çevre için taraflara önemli kazanımlar sağlayabilecektir.

\section{KAYNAKÇA}

CANBAY, Nilay, "Nasıl Sürdürülebilir Otel Olunur?", Eko Yapı Dergisi, 2012, 36-54, s. 49, http://www.ekoyapidergisi.org/21-nasil-surdurulebilirotel-olunur.html (Erişim Tarihi: 08.07.2016).

CONTEMPORARY, Major, "Environmental Awareness", http://download. nos.org/srsec317newE/317EL23.pdf, (Erişim Tarihi: 16.07.2016).

ÇAVUŞOĞLU, Bora, Marka Yönetimi ve Pazarlama Stratejileri, Nobel Yayın, Ankara 2015.

DEMİR, Şirvan Şen ve Metin Kozak, “Turizmde Tüketici Davranışları Modelini Oluşturan Aşamalar Arasındaki İlişki", Turizm Araştırmaları Dergisi, Cilt 22, Sayı 1, 2011, s. 19-34.

DUNLAP, Riley E....[et al.], "Measuring Endorsement of the New Ecological Paradigm: A Revised NEP Scale”, Journal of Social Issues, Volume 56, No 3, 2000, s. 425-442.

ERTÜRK, Mümin, İşletme Biliminin Temel İlkeleri, Beta Yayınları, İstanbul 2006.

FALOLA, H. O. and OSIBANJO, A. O., "Effectiveness of Training and Development on Employees' Performance and Organisation Competitiveness in The Nigerian Banking Industry", Bulletin of the Transilvania University of Braşov, Volume 7, No 1, 2014, s. 161-170. 
GÜVEN, Ezgi ve Murat Aydoğdu, “Çevre Sorunlarına Yönelik Farkındalık Ölçeğinin Geliştirilmesi ve Öğretmen Adaylarının Farkındalık Düzeylerinin Belirlenmesi”, Öğretmen Eğitimi ve Eğitimcileri Dergisi, Cilt 1, Sayı 2, 2012, s. $185-202$.

KILIÇ, Burhan ve Ali Eleren, "Turizm Sektöründe Hizmet Kalitesi Ölçümü Üzerine Bir Literatür Araştırması”, Alanya İşletme Fakültesi Dergisi, Cilt 1, Sayı 1, 2009, s. 91-118.

QIRIC, Eleina, "Analysis of Consumers Profile as an Important Tool for Tourism Development", Journal of Knowledge Management, Economics and Information Technology, Issue 7, 2011, s. 1-12.

SAGHIER, Niveen El and Demyana Nathan, "Service Quality Dimensions and Customers' Satisfactions of Banks in Egypt", International Business Research Conference, Dubai, 4-5 April 2013, s. 1-13.

UPADHYAY, Arvind...[et al.], "Sustainable Operations in Hotel Industry", Turizm Journal, 2013, s. 1-10.

YAZICIOĞLU, Yahşi ve Samiye Erdoğan, SPSS Uygulamalı Bilimsel Araştırma Yöntemleri, Detay Yayıncılık, Ankara 2004.

\section{Summary}

In this article, the applicability of the sustainable hotel paradigm in tourism enterprises has been researched. It can be said that competition has increased in the world market, consumers' preferences have changed and consumer demands have increased in terms of environmental sensitivity. Sustainable hotel or green hotel activities include activities that include applications such as food safety, less energy, less environmentally hazardous emissions, use of materials for environmental protection, and recycled packaging materials.

Sustainability is noteworthy as one of the most important objectives aimed at all businesses. Increasing numbers of green hotels are increasing their environmental awareness as consumers' preferred accommodation centers. In order for successful businesses in the sector to succeed, it may be beneficial to increase consumer satisfaction, make environment-friendly practices, activities that emphasize human health, environmentally conscious employees, environmentally conscious products and efforts to leave a cleaner world for future generations.

The universe of the work consists of 530 people working in 9 hotels operating in Kocaeli Kartepe region. Therefore, the sample of the study was identified as 345 people. After the questionnaire application, SPSS analyzes were made using the information obtained from the participants. After the analysis, it was observed that the increase of the training was the effect of ensuring the sustainability of the enterprises. It has been determined that increasing the number of training has an impact on the prevention of environmental pollution. It 
was observed that the vast majority of participants (208 persons, 60.5\%) were primary school graduates and the result that more training oriented studies were required. There was a positive relationship between the lack of environmental pollution and the in-service training while meeting the needs of the consumers. Consumer demand for global competition is increasing and changing day by day. In addition, the worldwide disadvantages of technological developments and environmental pollution make it necessary for businesses to be more sensitive to the environment. Employees, employees, consumers, governments, nongovernmental organizations, etc. are required to develop sustainable hotel understanding and to enable businesses to be successful in the competitive market. Working together in a team spirit can provide positive contributions to all parties. 